\title{
Possible Targets for Phytotoxic Compounds
}

\author{
Peter BöGER \\ Lehrstuhl für Physiologie und Biochemie der Pflanzen, Universität Konstanz, \\ D-7750 Konstanz, Germany
}

(Received August 20, 1987)

\section{INTRODUCTION}

This article will briefly draw the reader's attention to plant-specific enzymes and biosynthetic pathways not yet targets for herbicide attack of which, however, some inhibition studies have been performed. Accordingly, only such inhibitors will be mentioned in some detail of which a definite plant-specific target is known or suspected. The contribution is based on a plenary lecture given at the 12th Annu. Meet. Pestic. Soc. Jpn. in Kawasaki 1986 and should address colleagues in the industry. An enlarged version of this article will appear in Ref. 1). Only recent key references are cited, and should be used as an entrance to older literature.*

Figure 1, representing a schematic plant cell, notes the topics which will be dealt with and shall guide the reader through the paper. Of course, also the mode of action of herbicides already commercialized is unknown in many cases or their targets are speculative, since often a rather complex multienzyme system is involved. For example, this holds true for the field of ammonia assimilation, for radicalinduced degradations or carotenogenesis. Undoubtedly, in future new inhibitory sites will be determined in complex metabolic pathways.

\section{PIGMENT FORMATION}

Very little is known on inhibition of chloro-

\footnotetext{
* Herbicides are used with common names. The chemical names of relevant herbicides are compiled e.g. in "Short Review of Herbicides," Hodogaya Chemical Co., Ltd., Tokyo, 1986.
}

phyll biosynthesis. $\delta$-Aminolevulinate is formed from glutamate via glutamate-1-semialdehyde along a plant specific pathway. Glutamate pseudosubstrates have been shown as inhibitors of $\delta$-aminolevulinate formation, like 4-amino-5-fluoro-pentanoic acid or 4-amino-5hexynoic acid. ${ }^{2,3)}$ Their mode of action apparently resembles gabaculine (3-amino-2,3dihydrobenzoic acid) which causes bleaching in expanding leaves and increases the level of glutamate semialdehyde. ${ }^{4)}$ The carotenoid pathway, as outlined by Fig. 2, is plantspecific and, beyond the processing of geranylgeranyl pyrophosphate, consists of a membrane-bound enzyme complex, which has been targeted by new inhibitors like dihydropyrones $^{5)}$ and pyrimidine derivatives like SAN $380 \mathrm{H}$ (unpubl. results of this laboratory, $c f$. Ref. 1)), which lead to accumulation of $\zeta$ carotene by inhibiting the third $\mathrm{H}$-desaturation step in the row of precursors. We could also show an influence of tetcyclacis on the formation of cryptoxanthin, the first hydroxylated xanthophyll. Recently, FMC 57020, 2-(2-chlorophenyl) methyl-4, 4-dimethyl-3 - isoxazolidinone, a herbicide with strong bleaching activity was investigated. ${ }^{6)}$ Apparently the formation of geranyl pyrophosphate is inhibited by disturbing the preceeding reaction(s). It should be noted that such studies can be performed with cell-free systems developed from the bluegreen alga Aphanocapsa (Synechocystis), the fungus Phycomyces and Chenopodium chloroplasts. Appropriate combination of homogenates from these species and organelles allows for cell-free biosynthesis of carotenoids (carotenes and xanthophylls) starting with 


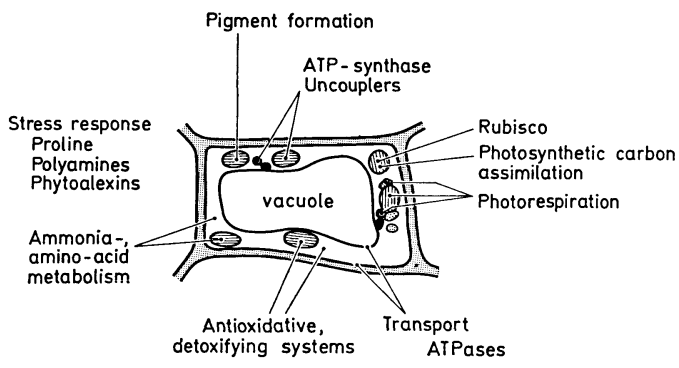

Fig. 1 Some plant-specific processes and enzymes are shown for a typical plant cell.

For these targets phytotoxic compounds are feasible, which may possibly lead to new herbicides.

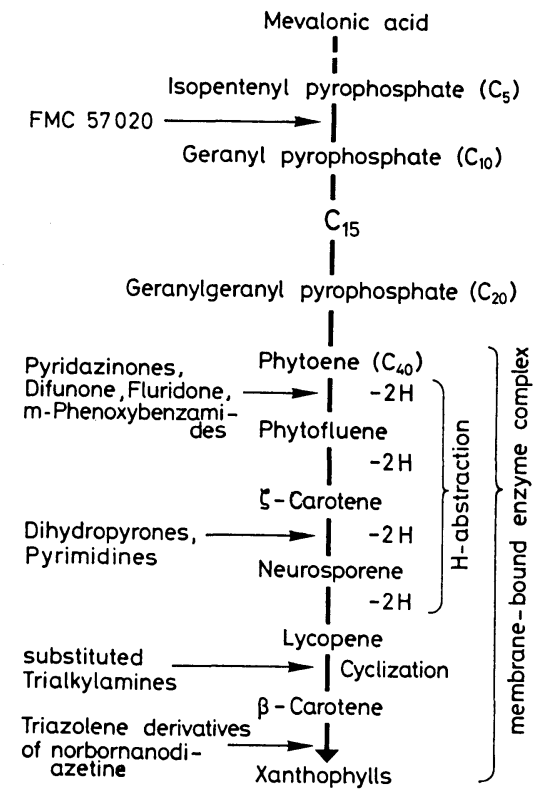

Fig. 2 Pathway of carotenogenesis starting with mevalonic acid leading to xanthophylls.

Sites of inhibition as known so far are indicated by arrows. For the first hydrogen-abstraction step at phytoene, catalyzed by phytoene desaturase (or dehydrogenase), quite a few bleaching compounds are known all leading to accumulation of phytoene. The inhibitor types indicated below the phytoene step have been characterized more recently; they cause accumulation of $\zeta$-carotene, lycopene and cryptoxanthin (a xanthophyll), respectively.

(radiolabeled) mevalonate. ${ }^{7,8)}$

\section{ATP-SYNTHASE, UNCOUPLERS}

The (plastidic) ATP-synthase catalyzes the terminal step of ATP-formation, i.e. combining inorganic phosphate with ADP. Inhibitors of this enzyme, which is located at the stromal face of the thylakoid, are also called "energytransfer" inhibitors. Known inhibitors are phlorizin, ${ }^{9)}$ anthraquinone dyes, ${ }^{10)}$ diphenylamines ${ }^{11)}$ or organic tin compounds. Generally such ATPase inhibitors also exhibit uncoupling activity that is, they abolish the $\mathrm{pH}$-gradient between the inner and outer side of the thylakoid vesicle thereby dissipating the energy needed for ATP-formation. A prominent inhibitor is tentoxin, a biogenic cyclic peptide produced by Alternaria alternata $f$. tenuis (Fig. $3)$. In a most elegant study ${ }^{12}$ it has been demonstrated that the plastidic coupling factor is its target, which is inherited in a nonMendelian fashion via the egg cell. ${ }^{13)}$ This crossing is similar to that of the herbicidebinding protein (D1-peptide) ${ }^{14)}$; consequently, the trait cannot be lost in a plant population by normal hybrid formation. Many uncouplers are known, the most active ones are salicylanilides ${ }^{15)}$ and benzylidenemalononitriles. ${ }^{16)}$ However, no herbicides have been developed as yet essentially operating as uncouplers.

\section{PHOTOSYNTHETIC CARBON METABOLISM}

$\mathrm{CO}_{2}$ assimilation starts with ribulose-1,5bisphosphate carboxylase ("Rubisco"). The $\mathrm{C}_{5}$-sugar phosphate combines with one molecule $\mathrm{CO}_{2}$ to yield two molecules of 3-phosphoglyceric acid which enters a $\mathrm{C}_{3}$-carbon reduction cycle (Calvin cycle) to be subsequently reduced (by NADPH and ATP) to the aldehyde phosphate. This triose phosphate sugar eventually produces a $\mathrm{C}_{6}$-sugar (yielding sucrose) and ribulose-1,5-bisphosphate is regenerated. Rubisco apparently is regulated through activation by $\mathrm{CO}_{2}\left(+\mathrm{Mg}^{2+}\right)^{17)}$ and inhibited in a diurnal cycle by a (phosphorylated) peptide. ${ }^{18)}$ As reported recently an activase may be responsible for the activation. ${ }^{19)}$ The activity of Rubisco essentially determines photosynthetic activity of the leaf. Schloss ${ }^{20)}$ has characterized the inhibition of Rubisco by 2- or 4carboxyarabinitol-1,5-bisphosphate, produced by chemical reduction of the intermediate in the carboxylation reaction. Both stereoisomers bind several orders of magnitude more tightly than the natural substrate. The com- 


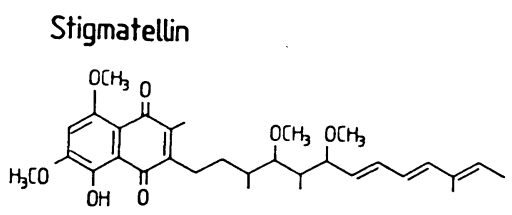

Tentoxin

( cyclo [- L - leucyl - N - methyl - (Z) - dehydro phenylalanyl - glycyl - N - methyl - L - alanyl])<smiles>CC(C)C(=O)NC(C(=O)N(C)C(=CP)C(=O)NCC1CCCCC1)C(C)C</smiles>

\section{Phaseolotoxin}

N( - amido - sulfamidophosphoryl) ornithyl - alanyl - homoarginine

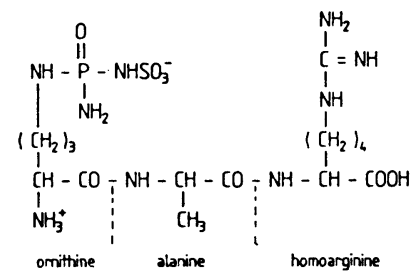

\section{Tabtoxin}

( Ser, Thr; $\mathrm{R}=\mathrm{H}, \mathrm{CH}_{3}$ )<smiles>[R]C(O)C(NC(=O)C(N)CCC1(O)CNC1=O)C(=O)O</smiles>

\section{Bialaphos}

L - 2 - amino - 4 - (hydroxymethylphosphinoyl) butyryl - $L$ - alanyl - $L$ - alanine

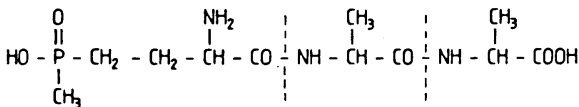

\section{Rhizobitoxine}

$$
\begin{aligned}
& 2 \text { - amino }-4-(2 \text { - amino - } 3 \text { - hydroxypropoxy })- \\
& \text { trans - but - } 3 \text { - enoic acid } \\
& \mathrm{OH} \\
& \mathrm{C} \mathrm{NH}_{2}-\mathrm{CH}-\mathrm{CH}_{2}-\mathrm{O}-\mathrm{CH}=\mathrm{CH}-\underset{\mathrm{NH}_{2}}{\mathrm{CH}-\mathrm{COOH}}
\end{aligned}
$$

Azaserine

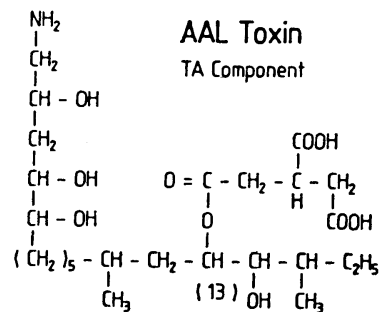

$$
\text { Cyanobacterin }
$$

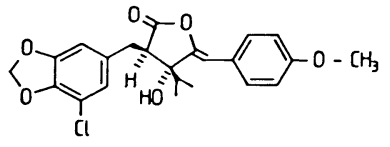

\section{Fusicoccin I}

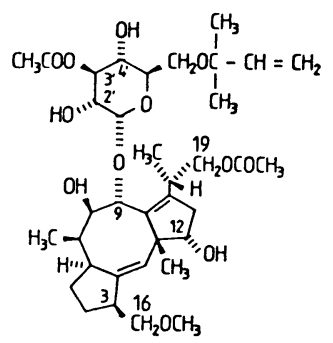

$\mathrm{CH}_{3}$

\section{Tabtoxinine.}

I B - lactam of 5 - amino - 2 - aminomethyl 2 - hydroxyadipic acid)<smiles>CNCC(O)(CCC(N)C(=O)O)C(=O)O</smiles>

\section{Oxetin}

$$
\mathrm{O}-\mathrm{CH}-\mathrm{COOH}
$$

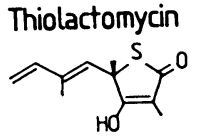<smiles>[N-]=[N+]=CC(=O)CCC(N)C(=O)OCC(N)C(=O)O</smiles>

Fig. 3 Biogenic compounds of microbial and fungal origin of known structure affecting plant enzymes.

Azaserine and DON (6-diazo-5-oxo-L-norleucine) are included as typical inhibitors of the glutamine: 2-oxoglutarate aminotransferase (GOGAT), although not plant-specific. 
pounds acts as a "slow-binding" inhibitor in a quasi irreversible fashion, although not covalently bound to the enzyme.

The Calvin cycle is a complex interplay of reactions whose regulations are in the beginning to be understood. ${ }^{21}$ Reduced thioredoxin, a 12-kD peptide, activates fructose-1,6-bisphosphatase and inactivates glucose-6-phosphate dehydrogenase. Micromolar concentrations of fructose-2,6-bisphosphate regulate the cytoplasmic fructose-1,6-bisphosphatase, dephosphorylation is the first step for sucrose synthesis.

There are reports on (artificial) inhibitors of photosynthetic carbon metabolism (e.g. for triosephosphate isomerase, pyruvatephosphate dikinase or glyceraldehyde-3-phosphate dehydrogenase). However, the $\mathrm{I}_{50}$-values are generally high. The reader is referred to Table 4 in Ref. 1).

Rubisco can fix carbon dioxide and molecular oxygen as well, both gases are competing. Thus under natural conditions, also phosphoglycolate is formed besides 3-phosphoglyceric acid the first entering a " $\mathrm{C}_{2}$-carbon oxidation" cycle (Fig. 4), which comprises the photorespiration. This cycle, located in peroxisomes and mitochondria, takes up oxygen, produces

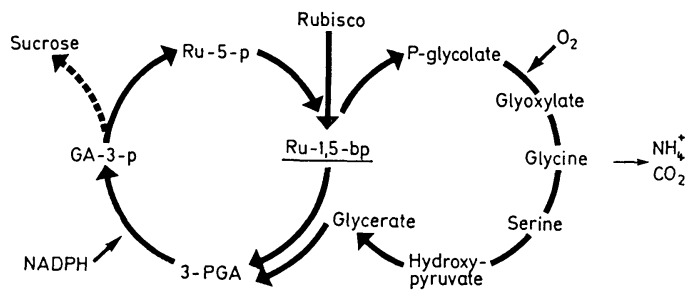

Fig. 4 Simple scheme on photosynthetic carbon assimilation $\left(\mathrm{C}_{3}\right.$-reduction cycle, left) and photorespiration $\left(\mathrm{C}_{2}\right.$-oxidation cycle, right).

Rubisco (=ribulose-1,5-bisphosphate carboxylase) can react both with $\mathrm{CO}_{2}$ and oxygen. The reaction products are 3-PGA (3-phosphoglyceric acid) and P-glycolate (phosphoglycolate). The first is converted to sugars, the latter yields glycine, serine and-in part-hydroxybutyrate, which may join the $\mathrm{C}_{3}$-reduction cycle again. The $\mathrm{C}_{2}$-carbon cycle also produces ammonia, $\mathrm{CO}_{2}$ and oxidized pyridine nucleotides, and consumes ATP. Ru-1,5-bp; ribulose-1,5-bisphosphate, Ru5 -p; ribulose-5-phosphate, GA-3-p; glyceraldehyde-3-phosphate.
$\mathrm{CO}_{2}$ and ammonia besides other organic compounds as indicated in the figure. ${ }^{22}$ Mutants with defects in photorespiration have been isolated (e.g. from Arabidopsis ${ }^{23)}$ ). They can be grown photosynthetically provided the oxygen pressure is low and $\mathrm{CO}_{2}$ increased thereby stalling photorespiration. Natural atmospheric condition leads to death. It is speculated that intermediates of the $\mathrm{C}_{2}$-oxidation cycle (glyoxylate?) may either inhibit crucial reactions or interfere with regulatory patterns. Conclusively, it is worthwile to look for inhibitors of photorespiration since these should definitely be phytotoxic. Unfortunately, little success has been reported. Glycolate oxidase (yielding glyoxylate) can be inhibited by 2-hydroxybutynoic acid ${ }^{24)}$ or 2-hydroxypyridinemethanesulfonic acid. ${ }^{25)}$

\section{MEMBRANE ATPASES}

They are located in the plasma membrane (plasmalemma) and vacuole membrane (tonoplast) and are transport ATPases. They hydrolyze ATP to allow for fluxes across the membrane, the specificity for certain ions or organic compounds most probably is ensured by coupled (transport) carriers. Plant ATPases actively move protons $\left(\mathrm{H}^{+}\right.$-ATPases). They are inhibited by e.g. diethylstilbestrol or $N, N^{\prime}$ dicyclohexylcarbodiimide, inhibitors which are not specific, also "synthesizing" ATPases in plastids and mitochondria are affected. Fusicoccin is a fungal excretion product (from Fusicoccum amygdali, Fig. 3) which specifically leads to an increase $\mathrm{H}^{+}$-efflux and concomitant $\mathrm{K}^{+}$-uptake through the plasmalemma. ${ }^{26)}$ The effect could recently be shown by intravesicular acidification with (inside-out) membrane vesicles. ${ }^{27)}$ Though analogs of fusicoccin have not been promising, a systematic screening for inhibitors, using model systems like that of Ref. 27) should by worthwhile.

It should be noted, that herbicides may affect the plasmalemma. Bentazon(e) increased both the cell turgor of protoplasts and induced stomatal opening, effects which could be counteracted by rotenone and antimycin, i.e. by ATP deprivation. ${ }^{28)}$ Uptake of sethoxydim into wheat leaf discs could be inhibited by the uncoupler carbonylcyanide- $m$-chlorophenylhydrazone and vanadate. ${ }^{29)}$ Vanadate is a 
specific, though not very active inhibitor of plasma membrane ATPases. It appears that some herbicides are actively taken up into plant cells via physiological carriers in connection with operating $\mathrm{H}^{+}$-ATPases.

\section{ANTIOXIDATIVE, DETOXIFYING SYSTEMS}

In aerobic redox systems (respiratory, photosynthetic) as present in plant cells, formation of free radicals, activated oxygen and peroxides is unavoidable. Some modern herbicide classes, like nitrodiphenyl ethers or cyclic imides increase the radical concentration in the cell ${ }^{30}$ ) (and unpubl. results) when activated by light. A first transient response of the plant against radical formation is ethylene production (stress response) followed by peroxidative degradations, which are irreversible. These can be determined by production of ethane originating from the breakdown of polyunsaturated fatty acids. The cells contain protective constituents to cope with radicalic disturbances. These are carotenoids, (reduced) glutathione (GSH) in connection with $\alpha$-tocopherol and ascorbate. The latter three represent an antioxidative and detoxifying system as indicated in Fig. 5. This system is linked to superoxide dismutase and catalase; details are given in. Ref. 31 ). Peroxidation only will occur, when $\alpha$-tocopherol, the direct radical quencher, cannot be adequately regenerated by reduced glutathione and ascorbate. For example, a strong decrease of the ascorbate level is observed when illuminated plants are exposed to (excess) oxyfluorfen. Furthermore, the activity of "regenerating" enzymes, like glutathione reductase or galactonolactone oxidase is increased as a response of the plant to radicalinducing compounds. ${ }^{32}$ The glutathione/ ascorbate system may be manipulated. Increase of the levels of regenerating enzymes may be performed by gene amplification leading to increased tolerance. ${ }^{33)}$ Enzymes involved may be inhibited, although at the moment only inhibitors affecting $\gamma$-glutamylcysteine synthetase have been reported. ${ }^{34)}$

It should be noted that (natural) "phototoxins" which are activated by light occur in higher plants (Asteraceae, Rutaceae) as defense agents. ${ }^{35)}$ This concept has been used to increase the amount of tetrapyrroles, the building

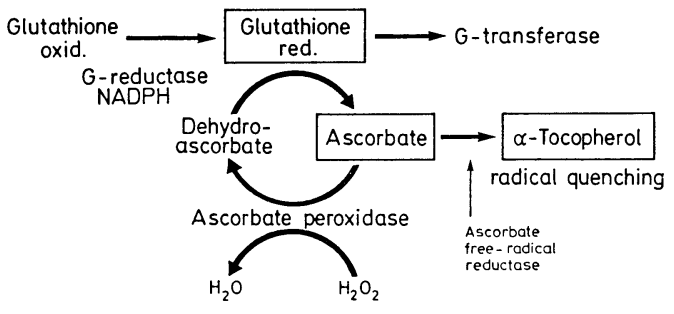

Fig. 5 The antioxidative and detoxifying glutathione system in the chloroplast.

Radicals and peroxides are quenched by $\alpha$-tocopherol which is (re)reduced by ascorbate. Ascorbate is regenerated from its dehydro form by reduced glutathione. The latter is enzymatically reduced by NADPH. Hydrogen peroxide is reduced by ascorbate catalyzed by an ascorbate peroxidase. The monodehydroascorbate radical, showing up in the course of redox reactions with ascorbate involved, may be reduced by pyridine nucleotides through an ascorbate free-radical reductase. ${ }^{60)}$ G-transferase is for transfer reactions, e.g. detoxifying xenobiotics.

stones for chlorophyll biosynthesis, by certain chemicals. ${ }^{36)}$ Apparently singlet oxygen is generated leading to lethal degradations.

The detoxifying capacity of reduced glutathione can be influenced by inhibiting the GSH $S$-transferase(s). Tridiphane is a prominent example. ${ }^{37)}$

\section{AMMONIA, AMINO-ACID METABOLISM}

Ammonia is essentially incorporated into amino acids via glutamine, originating from glutamate and catalyzed by glutamine synthetase. Glutamine is used by glutamate synthase (GOGAT) to form glutamate. Inhibitors for these two key enzymes are listed in Table 1 with references. Not too much enzymology is known for these compounds, undoubtedly bialaphos or better its active principle, phosphinothricin (PPT) has received most attention. PPT blocks photosynthesis leading to strong ammonia accumulation in the leaf and is effective in the light. ${ }^{38)}$ The herbicide is inhibitory under photorespiratory conditions only and can be counteracted by petiolar feeding of glutamine ${ }^{39,40)}$ although glutamine even increases the ammonia level. Apparently the depletion of glutamine is a crucial herbicidal effect rendering the $\mathrm{C}_{2}$-carbon oxidation cycle 
Table 1 Interference of inhibitors with nitrogen metabolism.

\begin{tabular}{llr}
\hline \multicolumn{1}{c}{ Inhibitor } & \multicolumn{1}{c}{ Target enzyme } & Key references \\
\hline $\begin{array}{l}\text { Bialaphos } \\
\text { Phosphinothricin (PPT) and analogs }\end{array}$ & & $61)$ \\
$\begin{array}{l}\text { Phosalacine (PPT-alanylleucine) } \\
\text { Methioninesulfoximine }\end{array}$ & Glutamine synthetase & $39), 40), 53)$ \\
Tabtoxin & & $62)$ \\
(Oxetin) & Glutamate synthase or & $53)$ \\
Diazooxonorleucine & Glutamine: 2-oxo-glutarate & $63)$ \\
Azaserine & aminotransferase (GOGAT) & $64)$ \\
Phaseolotoxin & Ornithine carbamoyl-transferase & $65)$ \\
Rhizobitoxine & B-Cystathionase & $66)$ \\
AAL-toxins & Aspartate carbamoyl-transferase & $43)$ \\
Acetamidooxyacetic acid & Aminotransferases & $67)$ \\
Benzamidooxyacetic acid & (ala, asp) & $68)$ \\
Isonicotinic acid hydrazide & Glycine/serine transaminase & $69)$ \\
Aminoacetonitrile & Glycine decarboxylase & $70)$ \\
\hline
\end{tabular}
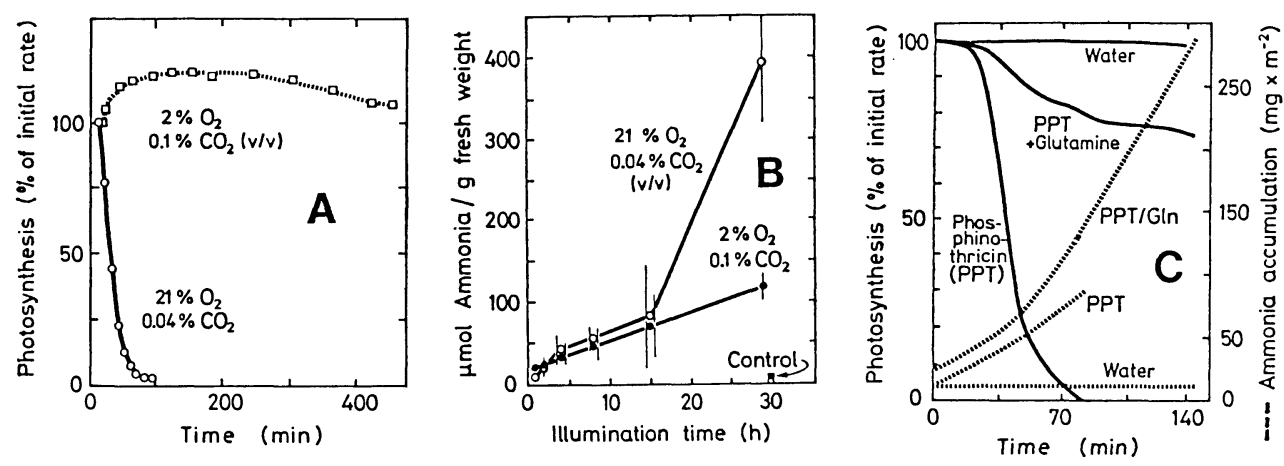

Fig. 6 Influence of phosphinothricin (PPT) on primary leaves of mustard; petiolar feeding. (A) Photosynthesis measured under photorespiratory $\left(21 \% \mathrm{O}_{2} ; 0.04 \% \mathrm{CO}_{2}, \mathrm{v} / \mathrm{v}\right)$ and nonphotorespiratory conditions $\left(2 \% \mathrm{O}_{2} ; 0.1 \% \mathrm{CO}_{2}, \mathrm{v} / \mathrm{v}\right)$. (B) Accumulation of ammonia under the conditions of (A), and (C) alleviation of PPT inhibition by concurrent supply of glutamine (Gln). Photosynthesis (left ordinate, solid line) and ammonia accumulation (right ordinate, dashed lines) is shown. Water=control leaves (drawn after data from Ref. 39), 40)).

inoperative. This hypothesis is corroborated by studies with barley mutants lacking glutamine synthetase. ${ }^{41)}$ Recent data on PPT mode of action are shown in Fig. 6.

Phaseolotoxin is the "halo-blight" toxin, produced by some strains of Pseudomonas syringae, leading to ornithine accumulation since the ornithine carbamoyl-transferase is affected. ${ }^{42}$ The AAL-toxins (see Fig. 3; Table 1 for references.) are of fungal origin and cause the "stem canker" (of tomato) by inhibiting aspartate carbamoyl-transferase, an enzyme instrumental in the pathway producing pyrimidine nucleotides. Detailed enzymology is still lacking but it appears reasonable to look for other inhibitors affecting these important enzymes. The same holds true for rhizobitoxine which is excreted by some strains of Rhizobium japonicum. $\quad \beta$-Cystathionase is the target which cleaves $\beta$-cystathionine to produce 
homocysteine, a precursor in the biosynthetic pathway to methionine. ${ }^{48}$ The inhibition of 5enolpyruvylshikimate-3-phosphate synthase by glyphosate is omitted here, since many papers cover this herbicide ${ }^{44}$; also for inhibitors of acetolactate synthase the reader is referred to recent references. ${ }^{45,46)}$

\section{POLYAMINES, PHYTOALEXINS}

Putrescine, spermidine and spermine have been ascribed a role in stresses induced by water deficit, $\mathrm{pH}$ or $\mathrm{K}^{+}$-deficiency. Cereal leaf segments exposed to osmotic stress exhibited a 60 -fold increase in putrescine, paralleled by a higher activity of arginine decarboxylase since putrescine is formed from arginine. ${ }^{47)}$ This enzyme is irreversibly affected by DL- $\alpha$ difluoromethylarginine and canavanine. See Ref. 48) for distribution of polyamines in plant tissue, Ref. 49) for more inhibitors.

Phytoalexins are typical plant products, synthesized after infection by fungi or bacteria. Often they are phytotoxic leading to death of both the host-plant cells and the parasite. Typically, they are produced at the infection site only where necrotic spots are observed.
More than 100 different phytoalexins have been described (see Ref. 50) for comprehensive reviews, Ref. 51) for chemical structures). Phytoalexins are induced by "elicitors" which may be abiotic (like heavy-metal ions) or organic and possibly cell-specific. A glucomannan has been isolated released from the cell wall of soybean infected by Phytophthora megasperma. ${ }^{52)}$ Details are still speculative, so is the mode of action which may be (in part) inhibition of respiration or induction of (ion) leakage of membranes. At any rate, phytoalexins should receive more interest because many of them have proven their phytotoxic potential already in "natural" bioassays.

\section{A VIEW ON BIOGENIC COMPOUNDS}

About 5000 are known as being microbially produced and quite a few are phytotoxins. Most of them have been isolated first in Japan, the majority are formed by Streptomyces strains and fungi. Evidently, natural inhibitors may serve as lead structures for phytotoxic compounds, although until now success in the herbicide field is not overwhelming. A good example is the development of the bleaching
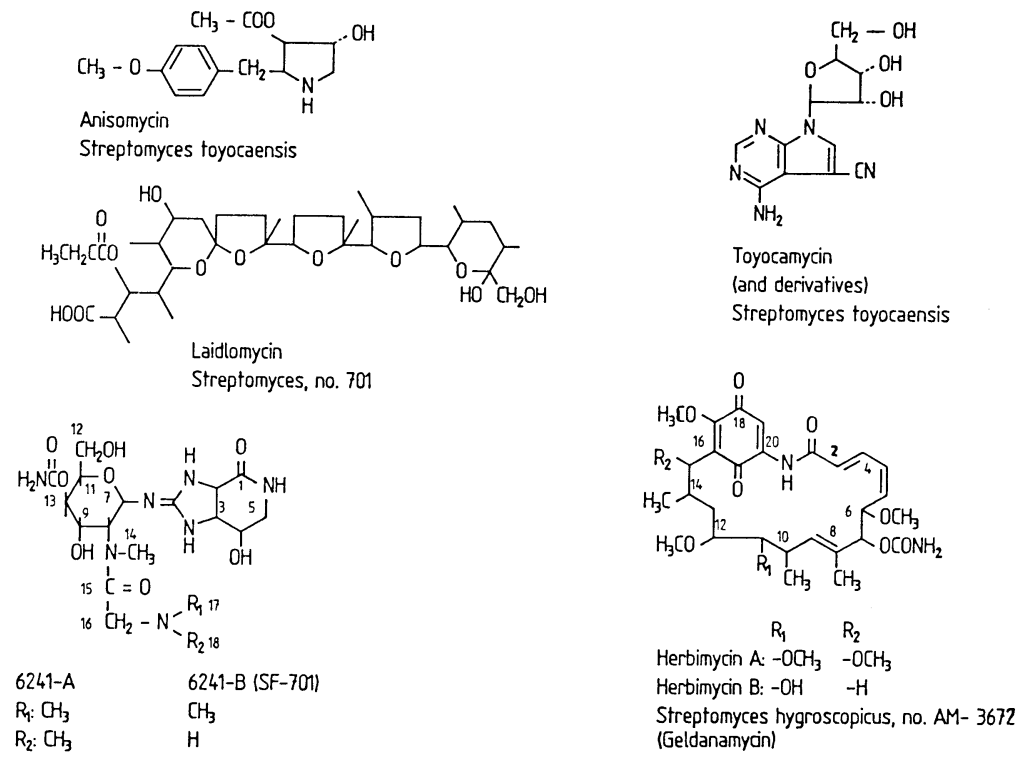

Fig. 7 Antibiotics from Streptomyces strains with phytotoxic activity and known chemical structure but unknown target.

For anisomycin and toyocamycin see Ref. 53), for laidlomycin Ref. 58), for 6241-A, B Ref. 59) and for herbimycins Ref. 55). 
and rice-selective herbicide kayametone from anisomycin. ${ }^{53,54)}$

A biogenic compound generally is present within a mixture of components and produced in low concentrations. Detection of the phytotoxic principle in the culture broth or during purification steps has to be done by bioassays which should be simple, sensitive and of broad response. Bioassays use the growth of internode segments, inhibition of germination ${ }^{55}$ or the Lepidium assay. ${ }^{56)}$ In Japan the starch-synthesis inhibition assay has been successfully applied. ${ }^{57)}$ Figure 7 demonstrates some structures of Streptomyces products of which phytotoxic activity and selectivity in rice has been demonstrated although the mode of action is unknown. Laidlomycin apparently has uncoupling activity. ${ }^{58)}$ For anisomycin and toyocamycin see Ref. 53); see Ref. 55) for herbimycins and Ref. 59) for antibiotics 6241$\mathrm{A}$ and $\mathrm{B}$.

\section{REFERENCES}

1) P. Böger: "Target Sites of Herbicide Action," ed. by P. Böger \& G. Sandmann, CRC Press, Boca Raton, FLA, 1988, in press

2) D. H. Flint: Plant Physiol. 75 (Suppl.), abstract No. 965, 170 (1984)

3) D. H. Flint: 27th Harden Conf., Wye, England (1986), abstract and personal communication

4) C. G. Kannangara \& A. Schouboe: Garlsberg Res. Commun. 50, 179 (1985)

5) J. Vial \& G. Borrod: Z. Naturforsch. 39c, 459 (1984)

6) G. Sandmann \& P. Böger: Z. Naturforsch. 42c, 803 (1987)

7) G. Sandmann \& P. Böger: "Target Sites of Herbicide Action," ed. by P. Böger \& G. Sandmann, CRC Press, Boca Raton, FLA, 1988, in press

8) G. Sandmann \& P. M. Bramley: Planta 164, 259 (1985)

9) G. D. Winget, S. Izawa \& N. E. Good: Biochemistry 8, 2067 (1969)

10) H. Strotmann, K. Brendel, K. S. Boos \& E. Schlimme: FEBS Lett. 145, 11 (1982)

11) W. Oettmeier: Z. Naturforsch. 34c, 1024 (1979)

12) B. R. Selman \& R. D. Durbin: Biochim. Biophys. Acta 502, 29 (1978)

13) R. D. Durbin \& T. F. Uchytil: Biochem. Genet. 15, 1143 (1977)

14) V. Souza-Machado \& J. D. Bandeen: Weed
Sci. 30, 281 (1982)

15) J. J. Schuurmans, E. C. I. Veerman, J. A. Francke, J. M. G. Torres-Pereira \& R. Kraayenhof: Plant Physiol. 74, 170 (1984)

16) H. Miyoshi, T. Nishioka \& T. Fujita: Biochim. Biophys. Acta 891, 293 (1987)

17) G. H. Lorimer \& T. J. Andrews: "Biochemistry of Plants," ed. by M. D. Hatch \& N. K. Boardman, Vol. 8, Academic Press, New York, pp. $330-374,1981$

18) J. C. Servaites: Plant Physiol. 78, 839 (1985)

19) A. R. Portis, M. E. Salvucci \& W. L. Ogren: Plant Physiol. 82, 967 (1986)

20) J. V. Schloss \& G. H. Lorimer: J. Biol. Chem. 257, 4691 (1982)

21) J. A. M. Holtum, G. J. Kelly \& E. Latzko: "Progress in Botany," ed. by H.-D. Behnke, K. Esser, K. Kubitzki, M. Runge \& H. Ziegler, Vol. 48, Springer Publ., Berlin and Heidelberg, pp. $97-123,1986$

22) P. Singh, P. A. Kumar, Y. P. Abrol \& M. S. Naik: Physiol. Plant. 66, 169 (1985)

23) C. R. Somerville: Annu. Rev. Plant Physiol. 37, 467 (1986)

24) P. J. Jewess, W. M. Kerr \& D. P. Whitaker: FEBS Lett. 53, 292 (1975)

25) J. Zelitch: J. Biol. Chem. 234, 3077 (1959)

26) E. Marré \& A. Ballarin-Denti: J. Bioenerg. Biomembr. 17, 1 (1985)

27) F. Rasi-Caldogno \& M. C. Pugliarello: Biochem. Biophys. Res. Commun. 133, 280 (1985)

28) A. H. Cobb, R. T. Rees, K. J. Nichols, P. R. Miller \& K. E. Pallett: Br. Crop Prot. Conf. 3 1187 (1985)

29) G. Retzlaff: unpubl. results (1987)

30) K. J. Kunert, G. Sandmann \& P. Böger: Rev. Weed Sci. 3, 1987, in press

31) B. Halliwell: "Chloroplast Metabolism-The Structure and Function of Chloroplasts in Green Leaf Cells," Clarendon Press, Oxford, 1984

32) A. Schmidt \& K.-J. Kunert: Plant Physiol. 82, 700 (1986)

33) A. Schmidt \& K.-J. Kunert: "Molecular Strategies for Crop Protection in Plants," ed. by C. J. Arntzen \& C. Ryan, UCLA Symp. Molec. Cell. Biol., Vol. 48, A. R. Liss Inc., New York, pp. 401-413, 1987

34) A. Meister: Science 220, 462 (1983)

35) K. R. Downum: "Natural Resistance of Plants to Pests, Role of Allelochemicals," ed. by M. B. Green \& P. A. Hedin, ACS Symp. Ser. No. 296, Am. Chem. Soc., Washington, D. C., pp. 197-205, 1986

36) C. A. Rebeiz, A. Montazer-Zouhoor, H. J. Hopen \& S. M. Wu: Enzyme Microb. Technol. 6, 390 (1984) 
37) G. L. Lamoureux \& D. G. Rusness: Pestic. Biochem. Physiol. 26, 323 (1986)

38) H. Köcher: Aspects Appl. Biol. 4, 227 (1983)

39) A. Wild, H. Sauer \& W. Rühle: Z. Naturforsch. 42c, 263 (1986)

40) H. Sauer, A. Wild \& W. Rühle: Z. Naturforsch. 42c, 270 (1986)

41) R. M. Wallsgrove, J. C. Turner, N. P. Hall, A. C. Kendall \& S. W. J. Bright: Plant Physiol. 83, 155 (1987)

42) R. E. Moore, W. P. Niemczura, O. C. H. Kwok \& S. S. Patil: Tetrahedron Lett. 25, 3931 (1984)

43) J. Giovanelli, S. H. Mudd \& A. H. Datko: Plant Physiol. 78, 555 (1985)

44) J. E. Franz: “Advances in Pesticide Science," ed. by H. Geissbühler, G. T. Brooks and P. C. Kearney, Vol. 2, Pergamon Press, Oxford, New York, Toronto, Sydney, Paris and Frankfurt, pp. 139-147, 1979

45) R. F. Sauers \& G. Levitt: "Pesticide Synthesis Through Rational Approaches," ed. by P. S. Magee, G. E. Kohn \& J. J. Menn, ACS Symp. Ser. No. 255, Am. Chem. Soc., Washington, D. C., pp. 21-44, 1984

46) M. Los: "Pesticide Science and Biotechnology," ed. by R. Greenhalgh \& T. R. Roberts, Blackwell Scient. Publ., Oxford and London, pp. 35-42, 1987

47) H. E. Flores, N. D. Young \& A. W. Galston: "Cellular and Molecular Biology of Plant Stress," ed. by J. L. Key \& T. Kosuge, A. R. Liss, Inc., New York, pp. 93-114, 1985

48) H. Felix \& J. Harr: Physiol. Plant. 1987, in press

49) P. Torrigiani, D. Serafini-Fracassini \& N. Bagni: Plant Physiol. 84, 148 (1987)

50) J. B. Harborne: "Natural Resistance of Plants to Pests," ed. by M. B. Green \& P. A. Hedin, ACS Symp. Ser. No. 296, Am. Chem. Soc., Washington, D. C., pp. 23-35, 1986

51) J. A. Bailey \& J. W. Mansfield (eds.): "Phytoalexins," Wiley and Sons, New York and Toronto, chapters 2-4, 1982

52) N. T. Keen, M. Yoshikawa \& M. C. Wang: Plant Physiol. 71, 466 (1983)

53) Y. Sekizawa \& T. Takematsu: "Pesticide
Chemistry-Human Welfare and the Environment," ed. by J. Miyamoto \& P. C. Kearney, Vol. 2, Pergamon Press, Oxford, New York, Toronto, Sydney, Paris and Frankfurt, pp. 261268, 1983

54) N. J. Poole \& E. J. T. Chrystal: Br. Crop Prot. Conf. 2, 591 (1985)

55) S. Omura, Y. Iway, Y. Takahashi, N. Sadakane, A. Nakagawa, H. Oiwa \& Y. Hasegawa: J. Antibiot. 22, 255 (1979)

56) F. R. Lehle \& A. R. Putnam: Plant Physiol. 69, 1212 (1982)

57) K. Takano: Agric. Biol. Chem. 49, 1299 (1985)

58) T. Kida \& H. Shibai: Agric. Biol. Chem. 50, 485 (1986)

59) T. Kida, T. Ishikawa \& H. Shibai: Agric. Biol. Chem. 49, 1839 (1985)

60) M. A. Hossain, Y. Nakano \& K. Asada: Plant Cell Physiol. 25, 385 (1984)

61) K. Tachibana: "Pesticide Science and Biotechnology," ed, by R. Greenhalgh \& T. R. Roberts, Blackwell Scient. Publ., Oxford and London, pp. 145-148, 1987

62) S. Omura, K. Hinotozawa, N. Imamura \& M. Murata: J. Antibiot. 37, 939 (1984a)

63) P. L. Langston-Unkefer, P. A. Macy \& R. D. Durbin: Plant Physiol. 76, 71 (1984)

64) S. Omura, M. Murata, N. Imamura, Y. Iwai, H. Tanaka, A. Furusaki \& T. Matsumoto: $J$. Antibiot. 37, 1324 (1984)

65) R. F. Pittillo \& D. E. Hunt: "Antibiotics," ed. by D. Gottlieb \& P. D. Shaw, Vol. I, Springer Publ., Berlin, pp. 481-493, 1967

66) J. G. Turner \& R. E. Mitchell: Plant Physiol. 79, 468 (1985)

67) D. Gilchrist, B. McFarland, D. Siler, S. Clouse \& A. Martensen: "Cellular and Molecular Biology of Plant Stress," ed. by J. L. Key \& T. Kosuge, A. R. Liss, Inc., New York, pp. 367-380, 1985

68) H. Nakamoto, M. S. B. Ku \& G. E. Edwards: Photosynth. Res. 3, 293 (1982)

69) G. Pritchard, W. Griffin \& C. P. Whittingham: J. Exp. Bot. 13, 176 (1962)

70) E. Creach \& C. R. Stewart: Plant Physiol. 70, 1444 (1982) 